\title{
EFEKTIFITAS PENGGUNAAN SOAL MODEL RIMA-HEURISTIK DALAM KREATIVITAS MATEMATIKA SISWA
}

\author{
Maria Dea Pramudita ${ }^{1 凶}$, Kadwi Mentari ${ }^{2}$, dan Monica Flaviyana ${ }^{3}$ \\ ${ }^{1,2,3}$ Prodi Pendidikan Matematika, Universitas Sanata Dharma Yogyakarta
}

\begin{abstract}
Info Artikel Abstract
Sejarah Artikel:

Diterima 17 Apr

2019

Direvisi 22 Mei 2019

Disetujui $25 \mathrm{Mei}$ 2019

Keywords: creativity, rhyme-heuristics

Paper type:

Research paper

This study aims to determine student's creativity in solving problems presented in the form of RimaHeuristics. Student creativity is observed through various ways of solving so that they get the right and right answers. The study was conducted using a qualitative descriptive model. The subjects studied were fifth grade elementary school students at Joannes Don Bosco Elementary School, Yogyakarta. The instruments used are written tests in the form of Student Worksheets (LKS). Data were analyzed by classifying the answers obtained by students and variations in answers from the results of student work, connecting with classification records (less creative, quite creative, and creative), and drawing conclusions. Based on the results of this research, students can find many answers in completing and various answers to what is given correctly and precisely. Based on the results of the data analysis conducted, it was obtained that some students found three correct and varied answers from those obtained by fifth grade elementary school students at the Joannes Don Bosco Elementary School, which students could categorize quite creatively from the abilities given. This Rima-heuroustic study has proven to be able to help in classroom learning to be more interesting and become an attraction for children to think creatively.
\end{abstract}

\begin{abstract}
Abstrak
Penelitian ini bertujuan untuk mengetahui kreativitas siswa dalam menyelesaikan suatu permasalahan yang disajikan dalam bentuk Rima-Heuristik. Kreativitas siswa diamati melalui beragam cara penyelesaian yang didapatkan siswa sehingga mendapatkan jawaban yang benar dan tepat. Penelitian ini dilakukan dengan menggunakan model deskriptif. Subjek yang diteliti dalam penelitian ini adalah siswa SD kelas V di SD Joannes Don Bosco, Yogyakarta. Instrumen penelitian yang digunakan berupa tes tertulis dalam bentuk Lembar Kerja Siswa (LKS). Data dianalisis dengan cara mengklasifikasikan banyaknya jawaban yang diperoleh siswa dan variasi jawaban dari hasil pengerjaan siswa, menghubungkan dengan catatan klasifikasi (kurang kreatif, cukup kreatif, dan kreatif), dan menarik kesimpulan. Berdasarkan hasil penelitian yang dilakukan tersebut diperoleh bahwa siswa mampu menemukan banyak jawaban dalam menyelesaikan permasalahan dan beragam jawaban dari suatu permasalahan yang diberikan dengan benar dan tepat. Berdasarkan dari hasil analisis data yang dilakukan diperoleh bahwa paling sedikit siswa menemukan tiga jawaban yang tepat dan beragam dari suatu permasalahan yang diberikan sehingga siswa SD kelas V di SD Joannes Don Bosco ini dapat dikategorikan siswa yang cukup kretif dari kemampuan-kemampuan yang mereka tuangkan dalam tes yang diberikan. Penelitian Rima-Heurustik ini ternyata dapat membantu dalam pembelajaran kelas menjadi lebih menarik dan menjadi daya tarik anak untuk berpikir kreatif.
\end{abstract}

(C) 2019 Universitas Muria Kudus

\} \text { Alamat korespondensi: } $\\{\text { Program Studi Pendidikan Matematika }} \\{\text { Fakultas Keguruan dan Ilmu Pendidikan Universitas Muria Kudus }} \\{\text { Kampus UMK Gondangmanis, Bae Kudus Gd. L. 1t I PO. BOX } 53 \text { Kudus }} \\{\text { Tlp (0291) } 438229 \text { ex.147 Fax. (0291) } 437198} \\{\text { E-mail: deapramudita29@gmail.com }} \end{array}$

p-ISSN 2615-4196

e-ISSN 2615-4072 


\section{PENDAHULUAN}

Kreativitas merupakan hasil interaksi antara individu dan lingkungannya, kemampuan untuk membuat kombinasi baru, berdasarkan data, informasi, atau unsur-unsur yang sudah ada atau dikenal sebelumnya, yaitu semua pengalaman dan pengetahuan yang telah diperoleh seseorang selama hidupnya baik itu di lingkungan sekolah, keluarga, maupun dari lingkungan masyarakat (Munandar, 2009).

Berkaitan dengan pengertian kreativitas terdapat beberapa tokoh yang memiliki pendapat yang hampir sama, diantaranya adalah: (1) Santrock (2002) berpendapat bahwa kreativitas adalah kemampuan untuk memikirkan sesuatu dengan cara-cara yang baru dan tidak biasa serta melahirkan suatu solusi yang unik terhadap masalah-masalah yang dihadapi; (2) Mayesty (1990) menyatakan bahwa kreativitas adalah cara berpikir dan bertindak atau menciptakan sesuatu yang original dan bernilai/berguna bagi orang tersebut dan orang lain; (3) Angelou berpendapat bahwa kreativitas ditandai dengan adanya kemampuan untuk menciptakan, mengadakan, menemukan suatu bentuk baru dan atau untuk menghasilkan sesuatu untuk melalui keterampilan imajinatif.

Dalam masyarakat berbasis pengetahuan, kreativitas dianggap sebagai sumber inovasi dan kemajuan (Sawyer, 2006). Metode RimaHeuristik melakukan banyak fungsi dalam pendidikan matematika awal. Dengan cara alami, mereka menarik perhatian pada konten yang akan diungkapkan dan memprovokasi anak-anak untuk mengantisipasi atau setidaknya mengharapkan kata-kata seperti itu di baris berturut-turut yang secara ritmik cocok dengan pola dan rima dengan anak-anak yang telah mendengarnya. Inilah sebabnya, seringkali, tidak perlu membaca kata akhir dari ritme kepada anak-anak: mereka dapat menyimpulkannya dari isi yang didengar sebelumnya dan akhirnya mengatakannya, terutama sajak itu adalah indikator tambahan. Ini mengembangkan pada anak-anak rasa ritme dan ketertiban yang akan menjadi penting dalam membentuk kemampuan matematika mereka di masa depan. Ini juga memacu rasa kepuasan, secara positif memengaruhi penilaian diri dan motivasi intrinsik, dan dengan demikian mengaktifkan lebih aktif mendengarkan. Menggunakan rima dalam mengajar matematika juga membantu mempraktekkan hafalan dan mendorong penciptaan gambar imajinatif, yang membuatnya lebih mudah, misalnya, untuk mengasimilasi konsep-konsep matematika abstrak. Selain itu, ketika mengungkapkan masalah matematika dalam banyak konteks situasional, rima meningkatkan pemahamannya dan mengajarkan fleksibilitas berpikir.

Dimana masyarakat saat ini tampaknya menyadari bahwa tidak cukup bagi individu untuk mempunyai sejumlah besar informasi, memprosesnya dan hanya memahaminya; mereka membutuhkan individu yang juga kaya akan kreativitas, menawarkan solusi untuk masalah yang tidak terpecahkan, dan menciptakan kemajuan yang akan mengarah pada kehidupan yang lebih baik.

Efektivitas merupakan dua kriteria yang biasa digunakan untuk menilai prestasi kerja dari suatu pusat pertanggung jawaban tertentu. Menurut Kartikahadi yang di kutip oleh Sukirno Agoes (2001), efektivitas adalah produk akhir kegiatan operasi telah mencapai tujuannya baik ditinjau dari segi kualitas hasil, kualitas kerja, maupun batas waktu yang ditargetkan.

Kreativitas pada dasarnya dimiliki oleh setiap anak, dimana anak-anak memiliki ciri-ciri yang sering digolongkan sebagai ciri individu kreatif oleh para ahli, ciri-ciri tersebut diantaranya: rasa ingin tahu yang besar, senang bertanya, imajinasi yang tinggi, berani menghadapi resiko, senang akan hal-hal yang baru, dan lain sebagainya. Meskipun demikian kreativitas anak juga dipengaruhi faktor orang tua, guru di sekolah, dan lingkungan merupakan faktor penting yang sangat mempengaruhi perkembangan kreativitas tersebut.

Peneliti menggunakan metode RimaHeuristik sebagai dasar untuk penelitian mutakhir mengenai kreativitas matematis dan bukan sebagai model/ alat untuk mengidentifikasi kemampuan kreatif atau individu yang kreatif. Banyaknya masalah yang sering muncul pada siswa yaitu siswa sering terpaku hanya pada satu jawaban soal sedangkan soal yang diberikan memiliki banyak jawaban. Upaya kami adalah untuk menawarkan pandangan yang luas dari studi penelitian yang telah dilakukan dengan metode Rima-Heuristik ini yang dapat berfungsi sebagai salah satu metode untuk penelitian lebih lanjut dalam kreativitas siswa untuk mampu berpikir lebih luas dan mampu memunculkan ide-ide lain dalam menjawab soal.

\section{METODE PENELITIAN}

Metode yang digunakan dalam penelitian ini yaitu metode penelitian deskriptif kualitatif. Penelitian dilakukan dengan menggunakan soal model Rima-Heuristik dan ditujukan kepada 
siswa kelas V SD Joannes Don Bosco. Dalam praktiknya, siswa diberikan soal model RimaHeuristik yang berisikan suatu permasalahan dalam ruang lingkup anak-anak. Soal tersebut disusun dalam bentuk sajak sesuai dengan model Rima-Heuristik dan dikerjakan secara mandiri oleh setiap siswa, serta siswa diminta menemukan berbagai variasi jawaban dari permasalahan dalam soal. Selanjutnya dari hasil pengerjaan siswa, peneliti melakukan analisis jawaban setiap siswa. Analisis dilakukan dengan berpedoman pada kriteria kreativitas berdasarkan penilaian kelas dan orisinalitas jawaban.

\section{HASIL DAN PEMBAHASAN}

Bagian ini akan dipaparkan hasil penelitian. Peneitian ini diakukan terhadap siswa kelas V SD Joannes Don Bosco, Yogyakarta. Dalam penelitian banyaknya siswa di kelas tersebut adalah 25 orang. Siswa diminta menyelesaikan permasalahan yang diberikan dalam soal cerita yang dibentuk ke dalam model Rima-Heuristik dimana diperlukan pemahaman rima setiap baris dalam soal tersebut, sehingga siswa dapat memperoleh lebih dari satu jawaban yang bervariasi. Pertama-tama akan dibahas mengenai permasalahan yang diberikan kepada siswa untuk diselesaikan secara individu.

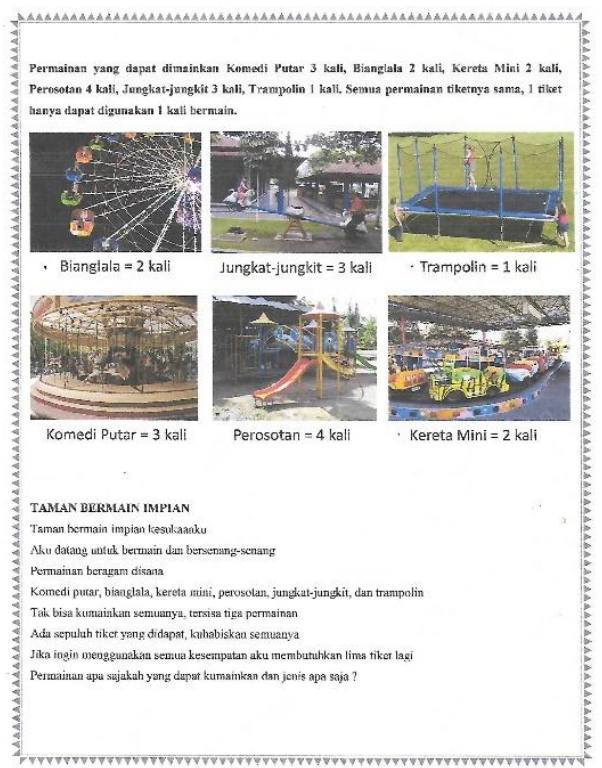

Gambar 1. Soal Model Rima-Heuristik

Kriteria yang ditetapkan pada Tabel 1 berikut didapat dari banyaknya jawaban yang didapatkan oleh masing-masing siswa, sehingga kriteria tersebut digunakan untuk menentukan

kreativitas siswa berdasarkan penilaian kelas yang diteliti.

Tabel 1. Kriteria kreativitas berdasarkan penilaian kelas

\begin{tabular}{cccc}
\hline & $\begin{array}{c}\text { Kurang } \\
\text { Kreatif }\end{array}$ & $\begin{array}{c}\text { Cukup } \\
\text { Kreatif }\end{array}$ & Kreatif \\
\hline $\begin{array}{c}\text { Banyaknya } \\
\text { jawaban }\end{array}$ & $2-4$ & $5-7$ & $8-10$ \\
\hline
\end{tabular}

Kriteria siswa "kurang kreatif" : siswa dikatakan kurang kreatif disini dilihat dari banyaknya variasi jawaban yang didapatkan siswa yaitu lebih atau sama dengan dua variasi jawaban dan kurang dari atau sama dengan empat variasi jawaban. Kriteria siswa "cukup kreatif" : siswa dikatakan cukup kreatif disini dilihat dari banyaknya variasi jawaban yang didapatkan siswa yaitu lebih atau sama dengan lima variasi jawaban dan kurang dari atau sama dengan tujuh variasi jawaban. Kriteria siswa "kreatif" : siswa dikatakan kreatif disini dilihat dari banyaknya variasi jawaban yang didapatkan siswa yaitu lebih atau sama dengan delapan variasi jawaban dan kurang dari atau sama dengan sepuluh variasi jawaban.

Tabel 2. Persentase Kreativitas Siswa Berdasarkan Penilaian Kelas

\begin{tabular}{|c|c|c|c|}
\hline & $\begin{array}{l}\text { Kurang } \\
\text { Kreatif }\end{array}$ & $\begin{array}{l}\text { Cukup } \\
\text { Kreatif }\end{array}$ & Kreatif \\
\hline $\begin{array}{l}\text { Banyaknya } \\
\text { jawaban }\end{array}$ & $2-4$ & $5-7$ & $8-10$ \\
\hline $\begin{array}{l}\text { Banyaknya } \\
\text { siswa yang } \\
\text { menjawab }\end{array}$ & 12 orang & 7 orang & 6 orang \\
\hline Persentase & $48 \%$ & $28 \%$ & $24 \%$ \\
\hline
\end{tabular}

Data diatas menunjukkan bahwa sebagian besar siswa di kelas tersebut mendapatkan banyaknya 2-4 jawaban yang artinya siswa "kurang kreatif" dalam menyelesaikan permasalahan yang diberikan.

Tabel 3. Banyaknya variasi jawaban yang diperoleh siswa

\begin{tabular}{cc}
\hline Banyak Jawaban & $\begin{array}{c}\text { Banyaknya siswa yang } \\
\text { menjawab }\end{array}$ \\
\hline 2 & 1 \\
3 & 8 \\
4 & 3 \\
5 & 3 \\
6 & - \\
7 & 4 \\
8 & 1 \\
9 & 2 \\
10 & 3 \\
\hline Dari analisis yang dilakukan dengan \\
melihat banyaknya jawaban yang didapatkan
\end{tabular}


siswa dan kriteria kreativitas yang ditetapkan, diketahui bahwa terdapat 12 siswa yang masuk dalam kriteria "kurang kreatif", 7 siswa yang masuk dalam kriteria "cukup kreatif", dan 6 siswa yang masuk dalam kriteria "kreatif", sehingga dari data diatas dapat diperoleh bahwa rata-rata kreativitas siswa di kelas yang telah diteliti adalah 5,48 maka siswa dikelas tersebut termasuk dalam kriteria "cukup kreatif".

Penelitian yang telah dilakukan memunculkan hasil bahwa siswa kelas V SD Joannes Don Bosco dapat berfikir kreatif, dimana siswa mampu mendapatkan banyak variasi jawaban dari permasalahan yang diberikan. Dari 25 siswa tidak semua mampu mendapatkan banyak variasi jawaban, ada yang hanya mendapatkan 2-4 variasi jawaban, 5-7 variasi jawaban, ada juga yang mendapatkan 810 variasi jawaban. Dari 25 siswa, diambil 3 sampel jawaban. Berikut adalah variasi jawaban dari 3 orang siswa yang masing-masing ada dalam kriteria kurang kreatif, cukup kretif, dan kreatif.
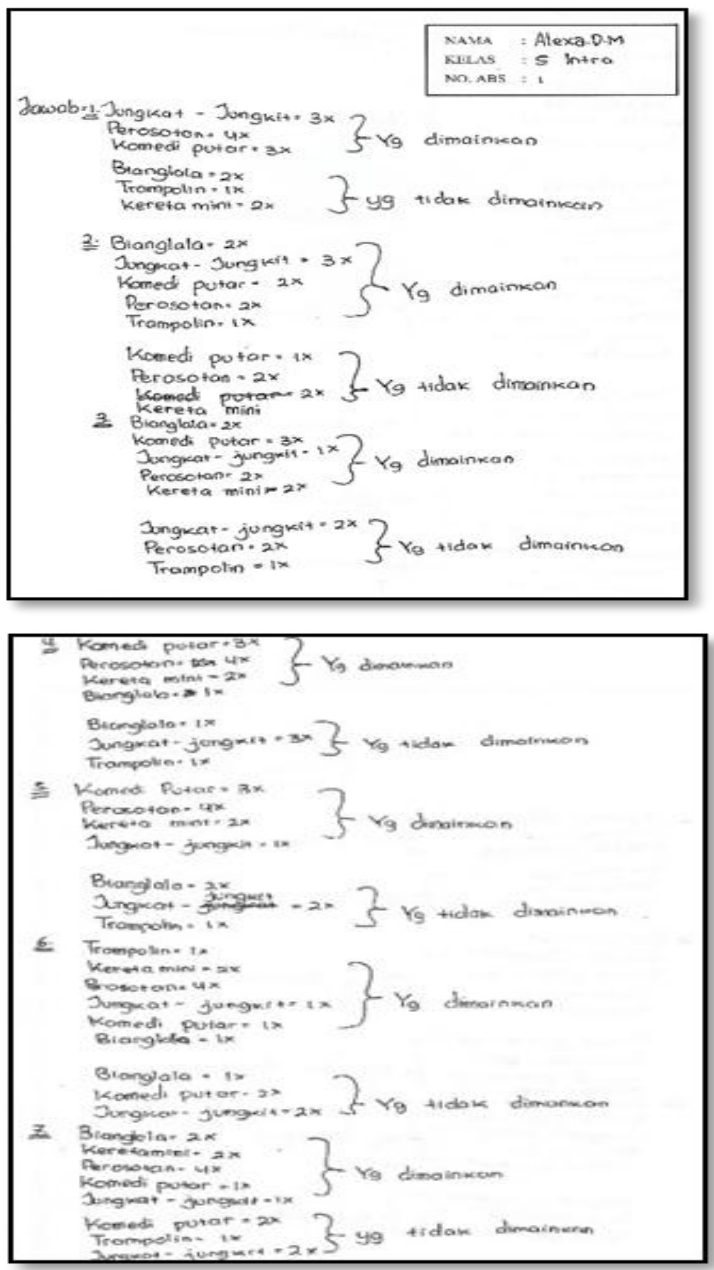

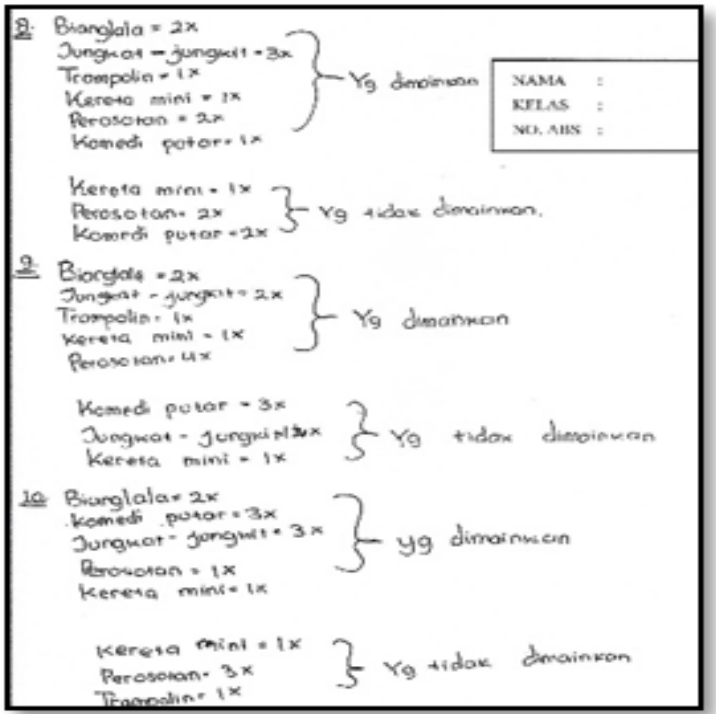

Gambar 1. Jawaban siswa yang kreatif berdasarkan kriteria penilaian kelas

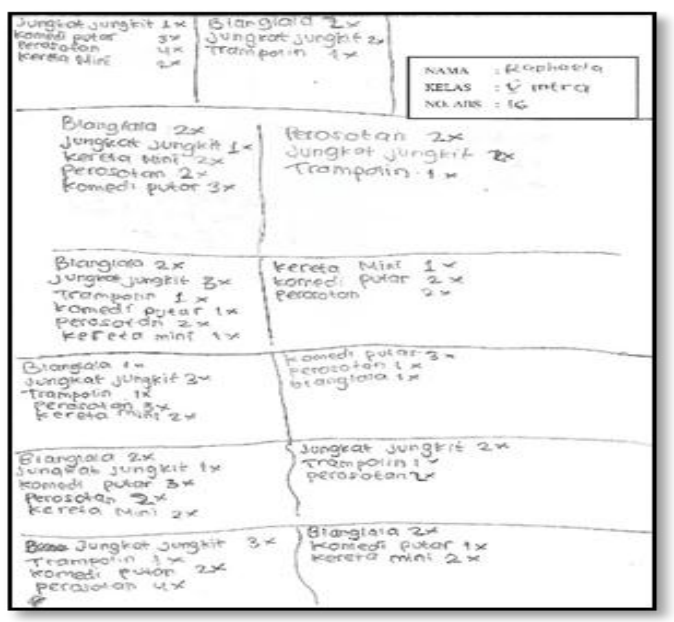

Gambar 2. Jawaban siswa yang cukup kreatif berdasarkan kriteria penilaian kelas.

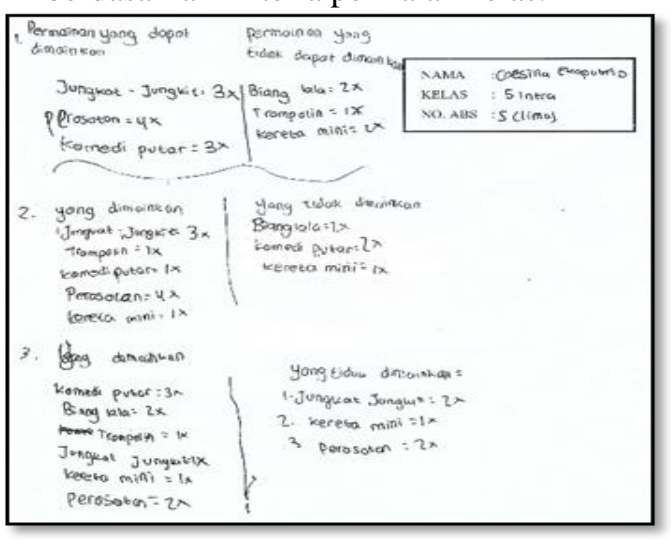

Gambar 3. Jawaban siswa kurang kreatif berdasarkan kriteria penilaian kelas. 
Tabel 4. Jenis jawaban yang diperoleh siswa

\begin{tabular}{clll}
\hline $\begin{array}{c}\text { Jenis } \\
\text { Jawaban }\end{array}$ & $\begin{array}{l}\text { Banyak } \\
\text { siswa }\end{array}$ & $\begin{array}{l}\text { Jenis } \\
\text { Jawaban }\end{array}$ & $\begin{array}{l}\text { Banyak } \\
\text { siswa }\end{array}$ \\
\hline Jenis 1 & 20 & Jenis 17 & 7 \\
\hline Jenis 2 & 2 & Jenis 18 & 9 \\
\hline Jenis 3 & 7 & Jenis 19 & 2 \\
\hline Jenis 4 & 3 & Jenis 20 & 2 \\
\hline Jenis 5 & 1 & Jenis 21 & 1 \\
\hline Jenis 6 & 3 & Jenis 22 & 2 \\
\hline Jenis 7 & 1 & Jenis 23 & 2 \\
\hline Jenis 8 & 3 & Jenis 24 & 1 \\
\hline Jenis 9 & 1 & Jenis 25 & 2 \\
\hline Jenis 10 & 2 & Jenis 26 & 1 \\
\hline Jenis 11 & 1 & Jenis 27 & 4 \\
\hline Jenis 12 & 2 & Jenis 28 & 6 \\
\hline Jenis 13 & 1 & Jenis 29 & 1 \\
\hline Jenis 14 & 1 & Jenis 30 & 1 \\
\hline Jenis 15 & 1 & Jenis 31 & 2 \\
\hline Jenis 16 & 1 & Jenis 32 & 6 \\
\hline
\end{tabular}

Data diatas menunjukkan bahwa terdapat 32 jenis jawaban yang diperoleh siswa di kelas tersebut. Jika ditinjau berdasarkan aspek orisinilitas jawaban, siswa dikatakan "kreatif" jika jawaban yang digunakannya berbeda dengan siswa lain atau dapat diartikan hanya siswa tersebut yang menggunakan jawaban itu. Sedangkan siswa dikatakan "kurang kreatif" jika jawaban yang digunakannya sama dengan siswa lain atau dapat diartikan bahwa jawaban tersebut sering digunakan.

Terdapat 12 jenis jawaban yang hanya digunakan oleh satu siswa saja, sedangkan 20 jenis jawaban lain digunakan oleh lebih dari satu siswa, sehingga jika kreativitas siswa di kelas tersebut dinilai berdasarkan aspek orisinilitas jawaban maka siswa di kelas tersebut termasuk dalam kategori "kurang kreatif" karena sebagian siswa menggunakan jawaban yang sama dengan siswa lain.

\section{SIMPULAN}

Berdasarkan hasil penelitian dan analisis yang dilihat dari dua aspek yang digunakan dalam menentukan kreativitas siswa di kelas V SD Joannes Don Bosco Yogyakarta yaitu aspek berdasarkan penilaian kelas dan aspek orisinilitas jawaban yang telah dilakukan pada kelas tersebut diperoleh kesimpulan bahwa dengan menggunakan soal model Rima-Heuristik efektif untuk memunculkan kreativitas siswa dalam permasalahan matematika yang memiliki jawaban bervariasi. Sebagai peneliti kami juga mengucapkan banyak terimakasih atas kerjasama pihak dari SD Joannes Don Bosco yang sudah mengizinkan kami untuk melakukan penelitian pada anak didik mereka. Kami juga ingin menawarkan beberapa penelitian lain yang dapat membantu untuk melihat kekreatifan siswa seperti penelitian mengenai jenis operasi aritmatika. Peneltian ini berfokus pada suatu operasi sederhana yang menggunakan simbolsimbol. Sehingga siswa dituntut untuk berpikir operasi apakah yang maksud dari simbol tersebut. Kami berharap sekiranya penelitian ini dapat membantu semua pihak maupun pembaca agar mendapatkan ide dalam memancing kekreatifan siswa dalam mangerjakan soal matematika.

\section{DAFTAR PUSTAKA}

Arifin, Zainal. 2011. Penelitian Pendidikan Metode dan Paradigma Baru. Bandung: PT.Remaja Rosdakarya.

Karwowski, Maciej., Dorota M. Jankowska., dan Witold Szwajkowski. 2017. Creativity, Imagination, and Early Mathematics Education. Springe International Publishing Switzer

Makmur, Agus. 2015. Efektifitas Penggunaan Metode Base Method Dalam Meningkatkan Kreativitas dan Motivasi Belajar Matematika Siswa SMP N 10 Padangsidimpuan.

PadangSidimpuan.

Pitta-Pantazi, Demetra., Maria Kattou dam Constantinos Christou. 2018. Mathematical Creativity: Product, Person, Process dan Press. Springer International Publishing AG.

Sujiono, Bambang dan Yuliani Nurani Sujiono. 2010. Bermain Kreatif Berbasis Kecerdasan Jamak. Jakarta: PT. Indeks. 